\title{
Case Studies of Sustainable Road Transport Practices in Different Industry Sectors in India
}

\author{
Anoop Khandelwal \\ School of Management, \\ G. D. Goenka University, Gurgaon, India. \\ E-mail: anoop.khandelwal@gmail.com, anoop.khandelwal@gdgu.org
}

(Received November 5, 2019; Accepted July 1, 2020)

\begin{abstract}
This study reviews actions taken by large companies in India to conform to environmental sustainability with a particular focus concerning road transport. The case study method was adopted. This entailed the researcher completing a questionnaire at face-to-face discussions with key informants in different companies across different industry sectors. The findings reveal significant congruence in adopting sustainability practices at business unit levels in general across diverse industry sectors but vary significantly in the transportation area due to segment-specific nuances. Further, it is seen that the sustainability steps are quite dependent on the nature of the products, cost of distribution related to the delivery points, and required reach of material. Research also shows that the stature of the companies expressly warrants that their policies and programs address the subject of sustainability in areas other than logistics and transportation. While this study is done across industry segments/verticals, it would be appropriate to investigate organizations within the same industry type to also establish if competition influences the width and depth of sustainability steps being taken by the Indian organizations.
\end{abstract}

Keywords- Environmental sustainability practices, Case studies on sustainability, Road freight transportation, Green logistics, and transportation.

\section{Introduction}

The development of transport networks has played a vital role in economic development in all countries. Freight transport, in all of its forms, provides access to goods, enables export and import, and is of high importance for virtually all industries and activities. It has been well- established that economic development requires a well-functioning transport system (OECD, 2003), however, it is also known that freight transport, especially the road transport sector is a significant contributor to a wide range of environmental and social problems. Road transport gives rise to various forms of air, water and land pollution, and noise pollution, contributing to global warming, and causes accidents as well as congestion (UNEP, 2000). Past studies have explored the steps that organizations adapt to address the aspect of sustainability in the overall functioning of their industries (Andersson and Holmberg, 2005; Preuss, 2005). Many organizations are in the earliest stages of integrating sustainability into their supply chain operations. For example, Gartner (2017) reports that $30 \%$ of respondents to a survey indicated that they have no or low-maturity sustainability initiatives, meaning that either they do not have a formal program to address sustainability today or sustainability initiatives are isolated, that is, they are tactical or reactive or driven by compliance.

Before delving deeper into the practices that large business corporations in India adopt to induct sustainability goals, one needs to define what is meant by the term sustainability.

The term sustainability first came into the lexicon of academic discourse after the 1992 Earth 
International Journal of Mathematical, Engineering and Management Sciences

Vol. 5, No. 6, 1091-1107, 2020

https://doi.org/10.33889/IJMEMS.2020.5.6.083

Summit in Rio. The United Nations Environmental Program (UNEP) was launched at this forum. Thereafter, business corporations have introduced a variety of initiatives such as 'Environmental Social Governance' (ESG), 'Environmental Management System' (EMS), and 'Green Supply Chain Management' (GSCM) (Rao, 2019).

In 1987, the United Nations World Commission on Environment and Development (WCED) published its definition of sustainability, "Development that meets the needs of the present without compromising the ability of future generations to meet their own needs" (p. 383).

Gartner defines sustainability as an objective that guides strategic and tactical decision-making with consideration to the three dimensions of social, economic, and environmental impacts of the decisions. Both these definitions have overarching common themes in that sustainability implies a longer-term view and it benefits all stakeholders through fostering positive social, economic, and environmental ramifications.

\section{Research Question and Study Objective}

This article captures the findings of sustainability practices used by large Indian business corporations towards contributing to the circular economy and analyzes whether there are generic practices or whether there are significant differences in practices that could be attributed to factors such as the core business of these companies.

Studies in the USA reveal that about 65\% of the country's (Bureau of Transportation, 2017) and about $75 \%$ of EU cargo (Eurostat, 2016) is transported by road. For India road transportation mode is used for about $80 \%$ of the total freight movement. Besides costs which can vary from one-third to two-thirds of the total logistic cost for various industries (Ghiani et al., 2004), the environmental impact of road transportation in carbon emission is quite significant.

Given the pressing problem of environmental degradation, the sustainable supply chain has become a major political, social, and technological priority for governments, corporations, and the public. Companies spend a considerable part of their supply chain and logistics cost on the distribution of the goods. Logistics related costs as a number of product cost range from $9 \%$ to $14 \%$ depending on the industry sector for companies (Cerasis Study, 2014). For organizations, these costs can be classified as inbound for raw materials and components, warehousing and outbound for finished goods. This study aims to pinpoint the specific steps that large Indian organizations are taking to limit their carbon footprints caused by their use of road transportation for the movement of goods and thus make this sector more sustainable.

\section{Justification of the Study}

A review of past studies, as evidenced in the literature review hereunder reveals that substantive research has been conducted on the theme of sustainability. However, these studies have been preeminently focused on developed countries. Because of variations in economic, social, cultural, legislative, and political conditions between India and these countries this study would potentially inform how road transport sustainability challenges are handled in a comprehensively different context. Also, additionally addressing the matter in a large canvas of supply chain and with a quantitative approach. Very few such studies have been done in a developing country like India about road transportation especially through invoking qualitative inquiry. Based on identifying this gap in knowledge, this study adds to the stock of knowledge to an important theme which would set these organizations as exemplar companies around which specific policy measures can be 
International Journal of Mathematical, Engineering and Management Sciences

Vol. 5, No. 6, 1091-1107, 2020

https://doi.org/10.33889/IJMEMS.2020.5.6.083

framed by the legislature for industries and businesses to follow.

\section{Literature Review}

A review of more than 100 research publications from 2007 to-date identified 35 publications that could potentially inform the current study. Analyzing these papers, it is possible to classify them in about six broad discourses as depicted in Table 1 below.

Table 1. Literature review summary

\begin{tabular}{|c|l|c|}
\hline Category split & \multicolumn{1}{|c|}{ Research area/subject-Sustainable transportation } & No of Articles/papers \\
\hline A & Optimization of transportation cost by way of an algorithm & 9 \\
\hline B & $\begin{array}{l}\text { Limiting of GHGs/CO2/Carbon emission by various } \\
\text { quantitative measures }\end{array}$ & 3 \\
\hline C & $\begin{array}{l}\text { Carbon emission from road transport in certain geography } \\
\text { other than India }\end{array}$ & 3 \\
\hline D & $\begin{array}{l}\text { Measures which 3PL companies are taking towards } \\
\text { sustainability in their organizations }\end{array}$ & 5 \\
\hline E & $\begin{array}{l}\text { Measures which companies, other than 3PL are taking } \\
\text { towards sustainability in their organizations }\end{array}$ & 2 \\
\hline F & $\begin{array}{l}\text { Measures which Indian companies, other than 3PL are } \\
\text { taking towards sustainability in road transportation in their } \\
\text { organizations }\end{array}$ \\
\hline
\end{tabular}

\section{Category A- Optimization of transportation cost by way of algorithm}

Out of the identified papers related to the subject, about $25 \%$ address and discuss the cost aspect of transportation (Leonardi and Baumgartner, 2004; Li et al., 2005; Szeto et al., 2012; Vidal et al., 2012; You and Jiao, 2014) wherein measures for enhancing of transportation efficiency leading to cost reduction using various types of quantitative algorithms are evaluated. The authors argue that carbon emission is directly proportional to the costs incurred in transportation, hence optimization of cost is essential. They have advocated the adoption of techniques such as computerized scheduling, variable route planning, fuzzy logic for route optimization, milk run, manufacturing scheduling, and road equilibrium to minimize greenhouse gas emissions.

Category B- Limiting of GHGs, $\mathrm{CO}_{2}$ and Carbon emission by various quantitative measures About $30 \%$ of research papers on transportation sustainability analyze different quantitative measures which organizations are taking to limit the emission of harmful gases (Coene et al., 2010; Brar and Saini, 2011; Andrieu and Pierre, 2012; Ruan et al., 2012; Arvidsson, 2013; Leonardi et al., 2014; Kuznetsov et al., 2016; Wang et al., 2018).These studies suggest that greenhouse gases (GHGs) $/ \mathrm{CO}_{2} /$ carbon emission can be reduced or controlled through actions such as transportation routing and milk run using scheduling techniques. They also talk about a physical logistics internet akin to world- wide- web by using a 13x13 matrix for sustainability measures (Montreuil, 2011). The authors' perspective is to critically adapt these techniques to make road transportation efficient.

\section{Category C-Estimation of carbon emission in certain geography}

Some authors (Piecyk and Mckinnon, 2010; Lagorio et al., 2016) have worked on estimation of carbon emission from road transport in the UK/countries other than India by 2020 . These studies do not address the specific measures to limit the emission of Greenhouse gases GHGs. 
International Journal of Mathematical, Engineering and Management Sciences

Vol. 5, No. 6, 1091-1107, 2020

https://doi.org/10.33889/IJMEMS.2020.5.6.083

Category D-Measures which 3 PL (Third-party logistics) companies are taking to offer a sustainable solution to their clients

Studies in this area from a $3^{\text {rd }}$ party logistics provider (3 PL) companies' perspective to define the various sustainable measures which such organizations are taking to control emissions are also available. But 3 PL companies touch the subject only from the transportation perspective and not from a larger organization angle (Evangelista, 2014; Evangelista et al., 2017).

\section{Category E-Sustainability steps taken by few organizations other than 3PL}

A few papers discuss practices that companies have introduced across several functional areas as initiatives to contain carbon footprints (Muller and Pfleger, 2014; Schaefer and Konur, 2015). One of the initiatives is by way of working with transport service providers (Manee-ngam and Udomsaksigool, 2014) in which there is cooperative tactical planning in road transportation with back hauling management in maximizing savings by enhancing capacity. These studies too have not addressed the key area or the targeted subject of measures regarding road transportation on an overall basis.

\section{Category F-Sustainability steps which Indian organization are taking}

The road transport sustainability practices that companies in India use are only partially addressed, and that too by about 5\% of published studies (Basu et al., 2015; Basu, 2016). Even these studies have used quantitative techniques in data gathering and therefore have not raised observations and comments from diverse stakeholders through in-depth questioning of key stakeholders.

\section{Research Methodology}

A case study was invoked to undertake the research. A case study is an in-depth study of a particular situation rather than a statistical survey (Tellis, 1997). Through a case study methodology, a researcher can go beyond the quantitative statistical results and understand the behavioral conditions through the subject's perspective. Although case study methods remain a controversial approach to data collection it is widely recognized in many Social Science studies, especially when in-depth explanations of social behavior are sought (Zainal, 2007). A case study is an empirical inquiry that investigates a contemporary phenomenon within a real-life context where the boundaries between phenomenon and context are not clearly evident, and in which multiple sources of evidence are used (Yin, 1984).

Further, the case study method enables a researcher to closely examine the data within a specific context. In most cases, it selects a small geographical area or a very limited number of individuals or organizations as the subjects of study. Case studies, in their true essence, explore and investigate current real-life phenomena through detailed related analysis of a certain number of events or conditions, and their relationships.

Conservation is a behavioral challenge and therefore needs behaviorally-informed solutions (The behavioral insights team, 2019). Since most steps towards Sustainability are more behavioral and attitudinal, it is felt that a case study is the most appropriate methodology for this research.

Evaluating the two approaches of case study, Qualitative \& Quantitative Research methods, it is understood that Qualitative is a research approach that examines concepts in terms of their meaning and interpretation in specific contexts of inquiry while Quantitative is a research approach that examines concepts in terms of amount, intensity or frequency (Ketokivi and Choi, 2014). 
International Journal of Mathematical, Engineering and Management Sciences

Vol. 5, No. 6, 1091-1107, 2020

https://doi.org/10.33889/IJMEMS.2020.5.6.083

Further, quantitative data, which is an outcome of mostly a structured study, can be quantified and verified and are amenable to statistical manipulation. In a logistics context, such data includes parameters like traffic flows, flows of goods, distances covered by a vehicle, orders from a store, or online e-commerce customers. On the other hand, qualitative data, which is obtained as a result of an unstructured study, such as opinions of stakeholders, cannot be measured directly. More simply, quantitative data define whereas qualitative data describe (Creswell, 2009).

The qualitative research interview is more appropriate for this study as it allows more flexibility and gives more factual data, which is difficult to obtain from other sources. The people interviewed work in supply chain function and have good knowledge of the freight transport system. Their opinions and views on the problem and potential solutions were of great importance to this study. Three industry verticals, as mentioned below, are considered for this study as these cover a significant portion $(\sim 60 \%$ - MoRTH report, 2013) of road freight transportation in India. Within, each industry sector/segment/vertical one company as stated below is included in the case study to get a good flavor of the larger picture of the Indian Industry as a whole:

(i) Fast-moving consumer goods (FMCG)-Beverage

(ii) Building material/Commodity -Cement

(iii) Healthcare- Pharma Devices

The following eight factors underpin discourses about the environmental impact of freight transportation (McKinnon and Woodburn, 1996; McKinnon, 2003):

- Structural factors, for example, number, location, and capacities of factories and warehouses.

- Commercial factors, for example, strategy and policies about sourcing and distribution.

- Operational factors, for example, scheduling of product flow.

- Functional factors, for example, management of transport resources, loads and routes.

- Product-related factors, for example, the nature of the product for transportation.

- External factors, for example, regulations and policies.

- Market dynamics, for example, competition.

- Environmental factors, for example, emission of GHGs and carbon.

Drawing on the above information, a questionnaire having eight sections, one for each factor, was developed. This Questionnaire was pretested through discussions with five experts in research design. Through discussions with senior managers, it was established who would be the most appropriate individuals in the organization with adequate knowledge to provide answers to the questions. Appointments were finalized with these 'key informants' and discussions were held through free-flowing face-to-face unstructured interviews and observations during the period of study. The empirical study was conducted over four weeks' in each organization.

Company selection criteria: Existing studies suggest that firm size may impact sustainable activities and outcomes. There is evidence suggesting that the adoption of sustainable practices is more likely at larger firms (e.g., Pagell, 2004). An organization's capability to innovate and the managerial orientation of being proactive and committed are precursors to successful sustainable supply chain management in conjunction with the alignment of the business model and the environmental and social elements of sustainability (Pagell and Wu, 2009). For this study, firms are selected using a purposive sampling approach for an experiment where innovative companies which are either leaders or among the top three in their industry segments and having revenue block of >INR 1000 
International Journal of Mathematical, Engineering and Management Sciences

Vol. 5, No. 6, 1091-1107, 2020

https://doi.org/10.33889/IJMEMS.2020.5.6.083

crores ( US\$140 m) are studied. Table 2 below depicts the details.

Table 2. Details of companies

\begin{tabular}{|c|c|l|l|c|}
\hline S. No. & Company & \multicolumn{1}{|c|}{ Description } & \multicolumn{1}{|c|}{$\begin{array}{c}\text { Revenue-India/ } \\
\text { Global }\end{array}$} & \multicolumn{1}{c|}{ Market } \\
\hline 1. & Beverage & $\begin{array}{l}\text { US MNC. World's top } \\
\text { beverage company }\end{array}$ & $\begin{array}{l}\text { INR10,000 } \\
\text { crores/USD 32 B }\end{array}$ & Soft drinks, tea, coffee, juices, etc. \\
\hline 2. & Cement & $\begin{array}{l}\text { Swiss MNC. World's } \\
\text { largest cement } \\
\text { company }\end{array}$ & $\begin{array}{l}\text { INR11,600 } \\
\text { crores/USD 27 B }\end{array}$ & Cement, Ready Mix Concrete (RMC) \\
\hline 3. & Pharma Devices & $\begin{array}{l}\text { US MNC. World's top } \\
\text { 3rd pharma company }\end{array}$ & $\begin{array}{l}\text { INR1200 crores/USD } \\
\text { 22 B }\end{array}$ & HealthCare \\
\hline
\end{tabular}

\section{Data Collection}

Besides the questionnaire, data was also gathered from publicly available sources like the company website, published articles, etc. This design allowed us to capitalize on triangulation. Triangulation involves combining observations from multiple researchers, data from multiple sources, and/or different types of data (in this study interview, archival and observational from the company premises visit) to mitigate biases and enhance reliability and validity (Jick, 1979; Eisenhardt, 1989; Yin, 1994).

Constant updating and improving the protocol after each replication is a foundation of grounded theory development (Glaser and Strauss, 1967). The same was adopted and followed in the study.

Further, for the case study to be robust, replication of data is important. Data analysis has two main components: within and across case analysis. Within the case, analysis helps us to examine sustainable supply chain management in a single context, while the across case analysis serves as a form of replication (Yin, 1994) where the constructs of interest in one setting are tested in other settings. This outcome from a literature review (LR) was also followed.

\section{Case Study Details}

7.1 Case Study 1: Beverage company to cover the industry vertical of FMCG/Retail.

\subsubsection{Introduction}

This company is part of USD 32 billion (2018 revenue) US-based parent company, which was founded in 1892 and is currently headquartered in Georgia, Atlanta, United States. The company in India employs about 25,000 people and does a business of USD 2.3 billion (INR 16,000 crores) per annum. The company is a producer, bottler, retailer, and marketer of non-alcoholic beverages and is well-known for its soft drink.

The company is doing some pioneering work in the area of sustainability in general and particularly in the area of transportation. It was observed that there was a considerable amount of enthusiasm and pride in some steps which they have taken in this area. The company is extensively committed to sustainability topics like Water stewardship, World without waste, and Fruit circular economy.

\subsubsection{The Scenario of Sustainability in Road Transportation}

The company requires huge amounts of fossil fuels for reaching its products to the remotest parts of the globe, therefore sustainability in road transportation is a very critical parameter. The 
International Journal of Mathematical, Engineering and Management Sciences

Vol. 5, No. 6, 1091-1107, 2020

https://doi.org/10.33889/IJMEMS.2020.5.6.083

company's focus is on areas like Driver training, health, and safety; distribution \& route optimization; \& minimization of turn-around- time (TAT) by reducing the bottlenecks. All these measures contribute to a reduction in emissions and cost optimization. Details on each are as under;

a) Driver training \& health-The company works with an empaneled pool of transporters whose drivers are trained such that they adhere to 'eco-driving' for getting best fuel efficiency. Eco-driving entails taking planned routes for their destinations, smooth acceleration of vehicles, maintenance of right tire pressure, and 'safe driving' to avoid any accidents. Every Yard (where vehicles are loaded in the bottling plants) has a Driver Management Center (DMC) where Driver Defensive Training (DDT) is conducted. The company believes that through DDT the driver should ensure not only accident-free trips but also defends itself, and also the products in turn, against any mishaps.

b) Route optimization- Freight consolidation approach using a hub and scope model to optimize loads for secondary distribution is adopted very efficiently (Allen et al., 2012). From the hubs, the trucks make about 7000 to 8000 shipments per day and all of its deliveries are within a radius of $200 \mathrm{~km}$. This is to ensure consistency in travel \& delivery time and as well as product penetration and reach. Most of the fleets is GPS enabled with output on mobile devices to keep close tracking of shipments such that any waiting time is minimized. These steps ensure optimum fuel consumption and limited carbon emission.

c) Pallet-wise shipping- This is truly a unique method adopted by the Company to ensure the utilization of vehicle capacity. All trucks used by the company are customized to carry bottles, cans, etc. in specifically sized pallets. This maximizes the cargo which is carried per trip thus minimizing the use of diesel fuel per $\mathrm{kg}$ of the load carried.

d) Use of alternate fuels- Compressed natural gas (CNG) fueled vehicles are used by the company wherever the fuel is available particularly in or near the metro cities. The company is also conducting trials in bio diesel to run the trucks. Further, the company plans to switch to electric vehicles as technology advances. Alternative fuels or renewal energy sources constitute about $20 \%$ of transportation.

e) Use of transport management system (TMS)- The company has recently rolled out transport optimization software by which vehicle routing will be more efficient than the manual process currently used and as well as their tracking can be done using a phone App. It is expected that through this measure company's transportation efficiency can improve by at least $15-20 \%$.

f) Strong bonding with suppliers: The company believes in long term partnerships with its suppliers. The majority of truckers have been associated with the company for more than $15-20$ years and are a part of the 'family' which ensures that the vendors ensure efficient and accident-free transportation with a focus on driver health. Further, these suppliers have amongst themselves become like a large 'supplier-supplier family' (Wu and Choi, 2005). This relationship has benefited all concerned parties. Amongst various facilities, all the 'Yards' of the company are equipped with restrooms and cafeterias for drivers to take adequate rest and never indulge in 'fatigued-driving'.

g) Driver recognition system: The company has a 'star system' of recognizing good drivers who are rated on a scale of 1 to 5 stars depending upon their performance and capabilities on key parameters of 'Global triangle of logistics' encompassing quality, delivery turn-around-time (TAT) and safety. Four to the five-star drivers are awarded suitably. 
International Journal of Mathematical, Engineering and Management Sciences

Vol. 5, No. 6, 1091-1107, 2020

https://doi.org/10.33889/IJMEMS.2020.5.6.083

On the final assessment at the end of the interview, it was quite evident that the company was indeed adopting crucial sustainability steps in the distribution of its products by road transportation. In recognition of the company's efforts towards sustainability, it was recognized as the 'MNC in India' for the year 2019 by the All India Management Association (AIMA).

7.2 Case Study 2: Cement company to cover the industry vertical of commodity/building material segment.

\subsubsection{Introduction}

This company has been operating in India for the last over 80 years. It is an India subsidiary of an MNC, a Switzerland headquartered US\$ 30 billion organization. The India unit has about 6,700 employees and does a business of about INR 11,000 crores (US\$ 1.6B). The company runs 17 factories and 75 Ready Mix Cement (RMC) plants. The company has over 50,000 dealers/distributors across India.

After about 4-5 hours of active interaction, the details on the questionnaire were completed and shared with the interviewee for any further inputs and comments, and any alterations/corrections in the responses. Few changes were suggested which were duly incorporated.

\subsubsection{Sustainability Steps Being Taken By the Company}

Due to the bulky nature of the product, logistics cost for the company is significantly higher at $25 \%$ of the Cost of goods sold (cogs), so optimizing this is critical. Levers for this are four-pronged Contract efficiency (rates), handle less (reduce handling/direct ship), move less (grinding plant near to consumption points), and move efficiently (Rail, route optimization, FTL \& damage reduction).

Environment Management System (EMS) is integrated into all activities of the value chain, from mining to sales to promoting the use of alternative fuels and resources, resulting in one of the lowest carbon footprints in its class

The company is part of the Cement Sustainability Initiative (CSI) in India, which is part of the World Business Council for sustainable development (WBCSD). It honors its commitment to making continued efforts to achieve the time-bound targets of the Low Carbon Technology Roadmap for the Indian Cement Industry leading to the years up to 2050.

Following are some of the key steps being taken by the company;

a) Use of Rail mode for transportation: The company transports $40 \%$ of its outbound material by railways. This is perhaps highest amongst all industry segments. These movements lead to a substantial reduction in fossil fuel usage and thus carbon footprints. There are practical difficulties in increasing this percentage due to the unavailability of railway wagons, limitations of deeper penetration of railway network in deeper pockets of the country, etc.

b) Promoting the use of Ready-Mix-Concrete: By this product mix, company avoids plastic-based packaging material/sacks usage and also optimizes transportation leading to fewer emissions. This product also leads to savings for the end-user in terms of transportation of concrete aggregate and also a significant amount of labor.

c) 'Move less, more efficient' approach: The company's Plants are geographically spread across the Country thus avoiding long-distance transportation. Integrated units are near the ore supply 
International Journal of Mathematical, Engineering and Management Sciences

Vol. 5, No. 6, 1091-1107, 2020

https://doi.org/10.33889/IJMEMS.2020.5.6.083

points. Grinding \& blending units are near the consumption points. Large conveyors are used in manufacturing plants to minimize handling and transportation.

d) Efficient \& Safe transport management: The company takes the following steps to enhance shipping efficiency;

i) Use of GPRS in vehicles: Almost 70\% of the company's 13,000 contracted trucks are equipped with these tracking devices. Journey Risk Management (JRM) parameters of safe driving, adherence to Eco-driving are measured by dashboards downloaded and prepared by Service providers at the end of every week. Fuel consumption, tracking of safety score, etc. are computed to determine transportation efficiency.

ii) Use of high capacity trucks: The company endeavors to ship material using trucks and trailers with high capacity to economize on freight and limit emission.

e) Driver Management Center (DMC): The company has a robust program of running Driver training and keeping its health records. Driver defensive training (DDT) is also covered to ensure defensive driving. High performers amongst the drivers are recognized by the reward and recognition system.

f) Other steps towards sustainability: Besides the above measures which primarily are in the area of 'road transportation', the company takes other significant steps in the overall area of sustainability as under;

i) Use of waste, recycling \& ore conservation: The company uses Slag (steel plant waste), Fly ash (thermal power plant waste), and Sludge (fertilizer plant waste) as raw materials for making innovative blends of cement. This also helps to conserve Limestone ore. Reuse of waste heat enhances the thermal efficiency of its manufacturing plants.

ii) Alternative fuel and Raw materials (AFRM) program: The company has a formal AFRM program wherein the use of alternative fuels in their captive power plants is adopted along with the use of wind energy.

7.3 Case Study 3: This study was conducted in a Healthcare company based out of Gurgaon.

\subsubsection{Introduction}

This company has been operating in India for the last over 25 years. It is an India subsidiary of a US\$ 16 billion American MNC. The India unit has about 1200 employees and does a business of about INR 1400 crores. The company has a factory near Gurgaon. It sells its goods directly to major hospitals and labs besides having over 350 dealers/distributors across India.

Interviews were conducted with the Operations leader over three sittings spread over four weeks.

\subsubsection{Sustainability Steps Being Taken By the Company}

Following are some of the key steps being taken by the company;

Being in the healthcare space, the company has to adhere to considerable regulatory measures like obtaining a drug licence, maintain the cold chain for its products, and monitor expiry dates of the material. Because of these conditions, some critical sustainability steps being taken are as under;

a) Scheduling \& Milk run of dispatches: Using TMS software (s/w), products are planned for shipment depending upon the scheduled date for delivery and as well as the maximum s/w 
International Journal of Mathematical, Engineering and Management Sciences

Vol. 5, No. 6, 1091-1107, 2020

https://doi.org/10.33889/IJMEMS.2020.5.6.083

determined quantity of each stock keeping unit (SKU) to ensure optimum capacity utilization of the truck. This minimizes the use of Part load trucking (PTL) and converts it into Full truckload (FTL) transportation.

b) Minimization of air transportation: Air shipment is not only 5-6 and 3-4 times costlier than road \& rail respectively, but it also emits the maximum amount of GHGs per $\mathrm{kg}$ per $\mathrm{km}$ basis (European Environmental Agency -EEA). The company endeavors to minimize air shipments to the best extent possible. Only about $15 \%$ of products needing chilled (2-8 degrees C) handling conditions are necessarily shipped by air to reduce transit time. For about $30 \%$ of the products which need a cold chain (15-25 degrees C), shipment is made by road using frozen cool packs to maintain the required temperature during transits.

c) Distribution Centers (DC) nearer to point of consumption: The company has designed its distribution network such as to ensure the least movement of material in transit. This keeps the distribution costs under control and as well as products reach faster to the customers maintaining required temperature conditions in transit. The company's eight DCs are located such that $80 \%$ of the material does not need a movement of $>100 \mathrm{kms}$.

d) Use of trucks with alternative fuels: The company encourages its transporters to use CNG fueled vehicles in metro cities to reduce its carbon footprints.

e) Other steps being taken by the company towards sustainability: The company's manufacturing plant has installed a large array of solar panels. Electricity obtained is used to run all the lighting needs of the factory. Recycled water is used for horticulture purposes.

\section{Research Findings}

For within-case analysis, the five key elements (Pagell and Wu, 2009) studied are i) influence of the company's business model on sustainability steps impacting operations ii) Organizations sustainability activities vis-à-vis the literature available, iii) Sustainability activities not covered in the LR, iv) Barriers \& facilitators/enablers for green steps \& finally v) Practices \& programs important for sustainability measures.

Cross case analysis is also carried out to establish patterns across organizations. This data is then displayed in a meaningful fashion (Miles and Huberman, 1994; Yin, 1994) in a construct by construct manner in the following two tables.

Compilation of the findings of the study of each company is tabulated below in two parts,

a) Table 3-Sustainability measures being taken by the organizations in the area of Road transportation; and

b) Table 4-Sustainability steps in general. 
International Journal of Mathematical, Engineering and Management Sciences

Vol. 5, No. 6, 1091-1107, 2020

https://doi.org/10.33889/IJMEMS.2020.5.6.083

Table 3. Sustainability steps in the area of road transportation

Executive summary: Sustainability in Road transportation- Major findings of case studies in large India based companies

\begin{tabular}{|c|c|c|c|c|c|c|}
\hline S. No. & $\begin{array}{l}\text { Sustainability } \\
\text { step }\end{array}$ & $\begin{array}{l}\text { Beverage } \\
\text { company }\end{array}$ & Cement company & $\begin{array}{l}\text { Healthcare } \\
\text { company }\end{array}$ & Key assessment & $\begin{array}{l}\begin{array}{l}\text { Remarks } \\
\text { comments }\end{array} \\
\end{array}$ \\
\hline 1 & $\begin{array}{l}\text { Use of } \\
\text { alternate/multi- } \\
\text { mode of } \\
\text { transportation }\end{array}$ & All by road & $\begin{array}{l}40 \% \text { shipments by } \\
\text { Rail }\end{array}$ & $\begin{array}{l}80 \% \text { by road, } 15 \% \\
\text { by air \& } 5 \% \text { by } \\
\text { rail }\end{array}$ & $\begin{array}{l}\text { Nature of the } \\
\text { product } \\
\text { influences the } \\
\text { transport mode }\end{array}$ & $\begin{array}{l}\text { Availability of } \\
\text { Railway for } \\
\text { micro- } \\
\text { distribution is a } \\
\text { challenge along } \\
\text { with handling }\end{array}$ \\
\hline 2 & $\begin{array}{l}\text { Use of alternate } \\
\text { fuels in road } \\
\text { transportation }\end{array}$ & $\begin{array}{lr}10-15 \% \text { use of } \\
\text { CNG, Bio-diesel } \\
\& & \text { Electric } \\
\text { vehicles } & \end{array}$ & $\begin{array}{l}\text { Only CNG, } \\
\text { wherever available }\end{array}$ & $\begin{array}{l}\text { CNG fuelled } \\
\text { vehicles used in } \\
\text { metro cities }\end{array}$ & $\begin{array}{l}\text { Mainly } \\
\text { determined by } \\
\text { the availability } \\
\text { of alternate fuels }\end{array}$ & $\begin{array}{l}\text { Alternate fuels } \\
\text { are }\end{array} \begin{array}{r}\text { only } \\
\text { available in } \\
\text { metro cities. } \\
\text { Battery } \\
\text { charging for } \\
\text { electric } \\
\text { vehicles is in its } \\
\text { infancy }\end{array}$ \\
\hline 3 & $\begin{array}{l}\text { Efficient } \\
\text { utilization of } \\
\text { trucking } \\
\text { capacity }\end{array}$ & $\begin{array}{l}\text { Customization of } \\
\text { trucks for } \\
\text { palletized } \\
\text { movement }\end{array}$ & $\begin{array}{l}\text { No customization, } \\
\text { use of standard } \\
\text { vehicles }\end{array}$ & $\begin{array}{l}\text { Uses s/w for } \\
\text { stuffing different } \\
\text { SKUs in various } \\
\text { truck sizes }\end{array}$ & $\begin{array}{l}\text { TMS is used to } \\
\text { optimize } \\
\text { shipment of } \\
\text { mixed SKUs }\end{array}$ & $\begin{array}{l}\text { System use is } \\
\text { more beneficial } \\
\text { to Beverage \& } \\
\text { Healthcare Cos. }\end{array}$ \\
\hline 4 & $\begin{array}{l}\text { Use of captive } \\
\text { fleet }\end{array}$ & $\begin{array}{l}\text { Has an } \\
\text { empanelled panel } \\
\text { of Transporters } \\
\text { with customized } \\
\text { fleet catering to } \\
80 \% \text { of the } \\
\text { requirement }\end{array}$ & $\begin{array}{l}\text { Has a shortlisted } \\
\text { pool of } 14,000 \\
\text { trucks }\end{array}$ & $\begin{array}{l}\text { Works with an } \\
\text { approved list of } \\
14-15 \text { transporters } \\
\text { using vehicles } \\
\text { with specified } \\
\text { quality }\end{array}$ & $\begin{array}{l}\text { Attached } \\
\text { transporters } \\
\text { ensure the } \\
\text { quality of fleet in } \\
\text { terms of age, } \\
\text { sizes \& } \\
\text { maintenance.10 } \\
\text { pt. checklist }\end{array}$ & $\begin{array}{l}\text { This helps to } \\
\text { ensure the best } \\
\text { fuel efficiency } \\
\& \text { low carbon } \\
\text { emissions }\end{array}$ \\
\hline 5 & $\begin{array}{l}\text { Routing \& Milk } \\
\text { run } \\
\text { shipments }\end{array}$ & $\begin{array}{l}200 \mathrm{~km} \text { range of } \\
\text { distribution }\end{array}$ & $\begin{array}{l}100 \mathrm{~km} \text { distribution } \\
\text { periphery }\end{array}$ & $\begin{array}{l}\text { Adopts } \\
\text { scheduling of } \\
\text { shipments along } \\
\text { with milk-run to } \\
\text { maximize } \\
\text { capacity } \\
\text { utilization } \\
\end{array}$ & $\begin{array}{l}\text { Cos adopt GPRS } \\
\text { tracking } \\
\text { majorly-40 to } \\
80 \%\end{array}$ & $\begin{array}{l}\text { Production } \\
\text { units/DCs are } \\
\text { close to the } \\
\text { point of } \\
\text { consumption to } \\
\text { optimize freight }\end{array}$ \\
\hline 6 & $\begin{array}{l}\text { Eco-driving } \\
\text { through Driver } \\
\text { training }\end{array}$ & $\begin{array}{l}\text { Huge thrust on } \\
\text { driver education, } \\
\text { health, and } \\
\text { training }\end{array}$ & $\begin{array}{l}\text { Journey Risk } \\
\text { Management } \\
\text { (JRM) being } \\
\text { adopted to ensure } \\
\text { Safety of man \& } \\
\text { material.21module } \\
\text { s of training }\end{array}$ & $\begin{array}{l}\text { Mainly left to the } \\
\text { transportation Co. } \\
\text { No direct } \\
\text { intervention. } \\
\text { Adherence } \\
\text { ensured by rates } \\
\text { fixation along } \\
\text { with technical } \\
\text { terms }\end{array}$ & $\begin{array}{l}\text { Beverage } \& \\
\text { cement Cos } \\
\text { adopt concepts } \\
\text { of Driver } \\
\text { Management } \\
\text { Centre (DMC) \& } \\
\text { Driver } \\
\text { Defensive } \\
\text { training (DDT) }\end{array}$ & $\begin{array}{l}\text { Major focus on } \\
\text { Driver training } \\
\text { \& welfare. Eco- } \\
\text { driving to get } \\
\text { best fuel } \\
\text { efficiency } \\
\text { thereby } \\
\text { reducing } \\
\text { emission }\end{array}$ \\
\hline
\end{tabular}

From Table 3 above, we can decipher the following;

Common actions toward green transportation:

-All companies though in different business segments are conscious enough to treat the subject of sustainability very seriously. Also, since all are leaders in their businesses and multinationals, they are cognizant of their brand image.

-It is also observed that all companies have significantly high logistics/transportation costs as a percentage of product costs $(9 \%-25 \%)$ due to the nature of products, hence, they are constantly innovating to optimize their shipping costs by few common actions like maximizing the capacity 
International Journal of Mathematical, Engineering and Management Sciences

Vol. 5, No. 6, 1091-1107, 2020

https://doi.org/10.33889/IJMEMS.2020.5.6.083

of transport, routing of a journey, driving efficiency, etc.

- All organizations lay high emphasis on vehicle health, driver welfare, education \& training and have formal dashboards to track compliance by the use of technology like GPRS, RFID, and systems like TMS.

- While distribution cost is a major driver, market share and competition are over-riding factors for all to ensure the availability of products to their customers.

- None of the organizations directly measure their carbon footprints or emissions caused by their transportation of products but focus on the efficiency of operations and steps like the use of alternate fuels and minimization of the movement of goods.

Table 4. Sustainability steps in general

\begin{tabular}{|c|c|c|c|c|c|c|}
\hline $\begin{array}{l}\text { S } \\
\text { No. }\end{array}$ & $\begin{array}{l}\text { Sustainability } \\
\text { step }\end{array}$ & $\begin{array}{l}\text { Beverage } \\
\text { company }\end{array}$ & Cement company & $\begin{array}{l}\text { Healthcare } \\
\text { company }\end{array}$ & Key assessment & $\begin{array}{l}\text { Remarks } \\
\text { comments }\end{array}$ \\
\hline 1 & $\begin{array}{l}\text { Sustainability } \\
\text { steps in } \\
\text { Manufacturing }\end{array}$ & $\begin{array}{l}\text { A commitment } \\
\text { of replenishment } \\
\text { of groundwater } \\
\text { to } 133 \% \text { of its } \\
\text { use }\end{array}$ & $\begin{array}{l}\text { Use of waste from } \\
\text { steel (slag), power } \\
\text { (ash) \& } \\
\text { fertilizer(molasses) } \\
\text { plants to conserve } \\
\text { Limestone }\end{array}$ & $\begin{array}{l}\text { Wastewater } \\
\text { recycling, solar } \\
\text { panels in Plant are } \\
\text { major steps taken. }\end{array}$ & $\begin{array}{l}\text { AFRM (alternate } \\
\text { fuel \& raw } \\
\text { material) approach } \\
\text { by the Cement Co- } \\
\text { Use of waste heat } \\
\text { energy \& wind- } \\
\text { power }\end{array}$ & $\begin{array}{l}\text { Use of solar } \\
\text { power by the } \\
\text { beverage \& } \\
\text { healthcare Cos } \\
\text { as a primary } \\
\text { energy source }\end{array}$ \\
\hline 2 & $\begin{array}{l}\text { Within } \\
\text { Corporate } \\
\text { Social } \\
\text { Responsibility } \\
\text { (CSR) } \\
\text { program }\end{array}$ & $\begin{array}{l}\text { Helped build } \\
\text { check dams \& } \\
\text { other water } \\
\text { conservation } \\
\text { projects }\end{array}$ & $\begin{array}{l}\text { Co promotes rural } \\
\text { and agricultural } \\
\text { development } \\
\text { activities like } \\
\text { education, women } \\
\text { empowerment \& } \\
\text { health \& sanitation }\end{array}$ & $\begin{array}{l}\text { Co runs various } \\
\text { programs to train } \\
\text { medical personnel for } \\
\text { safe use of devices, } \\
\text { medicines \& } \\
\text { reagents. Awareness } \\
\text { about TB \& Diabetes }\end{array}$ & $\begin{array}{l}\text { All companies } \\
\text { engage with } \\
\text { communities to } \\
\text { support education } \\
\text { \& healthcare }\end{array}$ & $\begin{array}{l}\text { For Beverage } \\
\text { Co. water } \\
\text { conservation is } \\
\text { critical. For } \\
\text { Cement Co. } \\
\text { preventing air } \\
\text { pollution is key } \\
\text { imperative }\end{array}$ \\
\hline 3 & $\begin{array}{l}\text { Product } \\
\text { marketing } \\
\text { \&Health } \\
\text { consciousness }\end{array}$ & $\begin{array}{l}\text { Address concern } \\
\text { of obesity by the } \\
\text { reduction in } \\
\text { sugar content in } \\
\text { its products \& } \\
\text { launch of more } \\
\text { fruit-based } \\
\text { beverages }\end{array}$ & $\begin{array}{l}\text { Special emphasis } \\
\text { on protective gear } \\
\text { like masks and } \\
\text { gloves during } \\
\text { handling }\end{array}$ & $\begin{array}{l}\text { The company } \\
\text { engages with } \\
\text { hospitals and health } \\
\text { centers to train on } \\
\text { AMR (Antibiotics } \\
\text { resistance), AIDS \& } \\
\text { other critical ailments }\end{array}$ & $\begin{array}{l}\text { All Companies are } \\
\text { leaders in their } \\
\text { segments, hence } \\
\text { right consumer } \\
\text { messaging \& \& } \\
\text { engagement is of } \\
\text { utmost importance }\end{array}$ & $\begin{array}{l}\text { Diversification } \\
\text { of Beverage Co } \\
\text { away from } \\
\text { aerated drinks is } \\
\text { important. } \\
\text { Promotion of } \\
\text { Ready-mix- } \\
\text { concrete (RMC) } \\
\text { for Cement Co } \\
\text { is the future }\end{array}$ \\
\hline 4 & $\begin{array}{l}\text { Sustainability } \\
\text { policy- } \\
\text { formally } \\
\text { available }\end{array}$ & $\begin{array}{l}\text { No formal } \\
\text { sustainability } \\
\text { policy. Follow } \\
\text { Environmental } \\
\text { Management } \\
\text { System (EMS) \& } \\
\text { Supplier } \\
\text { Guiding } \\
\text { Principle (SGP) } \\
\text { through which } \\
\text { environmental } \\
\text { parameters are } \\
\text { addressed }\end{array}$ & $\begin{array}{l}\text { Sustainable } \\
\text { Development } 2030 \\
\text { plan focusing on } \\
\text { four broad themes: } \\
\text { Climate, Circular } \\
\text { Economy, Water \& } \\
\text { Nature, and People } \\
\text { \& Communities. }\end{array}$ & $\begin{array}{l}\text { Co publishes its } \\
\text { Sustainability policy } \\
\text { on an annual basis. } \\
\text { Besides the measures } \\
\text { taken in its mfg. } \\
\text { plants, Co works with } \\
\text { 3PL partners globally } \\
\text { to maximize ocean \& } \\
\text { rail shipping and } \\
\text { minimize road } \\
\text { transportation. }\end{array}$ & $\begin{array}{l}\text { Commitment to } \\
\text { time-bound targets } \\
\text { of the Low Carbon } \\
\text { Technology } \\
\text { Roadmap for the } \\
\text { Indian Cement } \\
\text { Industry leading to } \\
\text { the years up to } \\
2050 \text {. Healthcare } \\
\text { Co works on the } \\
\text { motto of 'helping } \\
\text { all live healthy } \\
\text { lives' }\end{array}$ & $\begin{array}{l}\text { All Companies } \\
\text { are trendsetters } \\
\text { and competition } \\
\text { follows them. } \\
\text { Maintaining a } \\
\text { focus on } \\
\text { sustainability as } \\
\text { a corporate } \\
\text { focus area is of } \\
\text { most profound } \\
\text { vitality }\end{array}$ \\
\hline
\end{tabular}


International Journal of Mathematical, Engineering and Management Sciences

Vol. 5, No. 6, 1091-1107, 2020

https://doi.org/10.33889/IJMEMS.2020.5.6.083

Table 4 continued...

\begin{tabular}{|c|c|c|c|c|c|c|}
\hline 5 & $\begin{array}{l}\text { Community } \\
\text { engagement }\end{array}$ & $\begin{array}{l}\text { Co is supporting } \\
\text { communities, } \\
\text { building water } \\
\text { replenishment } \\
\text { structures, } \\
\text { working with } \\
\text { schools to } \\
\text { revitalize their } \\
\text { infra \& creating } \\
\text { awareness \& } \\
\text { inculcating the } \\
\text { habit of } \\
\text { recycling }\end{array}$ & $\begin{array}{l}\text { Improving road } \\
\text { safety in the } \\
\text { community - } \\
\text { Within 5Km of any } \\
\text { unit on-route to } \\
\text { schools \& colleges } \\
\text { and Dhabas, drive } \\
\text { campaign in } \\
\text { educational places, } \\
\text { panchayats, farmer } \\
\text { groups, Govt } \\
\text { bodies, etc. }\end{array}$ & $\begin{array}{l}\text { Engages in four } \\
\text { categories: } \\
\text { *Innovation - health care } \\
\text { safety, outcomes, and } \\
\text { cost } \\
\text { *Access - health care in } \\
\text { resource-limited } \\
\text { populations } \\
\text { *Efficiency - } \\
\text { environmentally sound } \\
\text { products \& resilient } \\
\text { operations } \\
\text { *Empowerment - } \\
\text { positive workforce and } \\
\text { community impacts. }\end{array}$ & $\begin{array}{l}\text { Beverage \& } \\
\text { Cement } \\
\text { companies } \\
\text { have } \\
\text { significant a } \\
\text { presence in } \\
\text { rural parts of } \\
\text { India. Their } \\
\text { CSR activities } \\
\text { focussing on } \\
\text { farmers } \\
\text { provides them } \\
\text { goodwill. } \\
\text { Healthcare co } \\
\text { engages more } \\
\text { in semi-urban } \\
\text { \& urban } \\
\text { hospitals \& } \\
\text { primary } \\
\text { healthcare } \\
\text { centres }\end{array}$ & $\begin{array}{l}\text { Being present in } \\
\text { India for } \\
\text { decades all } \\
\text { organizations } \\
\text { have engaged } \\
\text { with local } \\
\text { communities } \\
\text { well which } \\
\text { enhances their } \\
\text { sustainability } \\
\text { agenda along } \\
\text { with business } \\
\text { growth }\end{array}$ \\
\hline
\end{tabular}

Table 4 above details the sustainability steps being taken by these organizations in general. Key highlights are;

- All companies have formal sustainability policies and that the initiative is driven as a part of their overall corporate strategy thus landing enough weightage to this program.

- Corporate social responsibility (CSR) program though mandated by law, is being pursued by all the companies studied. Sustainability steps like water conservation, healthcare, and sanitation are addressed under the CSR activities as community engagements.

- Manufacturing Plants of all companies use solar power. But the use of waste items like slag, fly ash, and molasses for cement-making raw materials is a major thrust towards sustainability by the Cement company.

\section{Summary of Findings and Conclusions}

An organization's capability to innovate and the managerial orientation of being proactive and committed are precursors to successful sustainable supply chain management in conjunction with the alignment of the business model and the environmental and social elements of sustainability (Pagell and $\mathrm{Wu}, 2009$ ).

With all companies having the formal long-term policy, programs, and initiatives towards sustainability, it is evident they being leaders in their respective business segments are quite conscious of their social responsibilities to contribute to a circular economy. Neither competition nor the regulatory guidelines compel them to initiate steps on the environment front. They are selfdriven. Further, the following conclusions can be drawn;

a) Cost of transportation is a major driver for significant freight optimization measures that organizations take in their day to day operations. For all the Companies studied, the logistics costs are very high as a percentage of product cost -11 to $25 \%$. Thus, their main aim is to minimize and optimize expenses towards distribution.

b) The nature of the product also determines the stress and seriousness of sustainability steps that 
International Journal of Mathematical, Engineering and Management Sciences

Vol. 5, No. 6, 1091-1107, 2020

https://doi.org/10.33889/IJMEMS.2020.5.6.083

organizations take. In the current study all products, cement with key raw material inputs like ore, coal, etc., beverages which are dependent on the use of scarce water resources and healthcare/pharma products which are very sensitive for public health, are quite sensitive from an environmental perspective, hence need special focus and attention by the manufacturers.

c) Deep penetration of the product into the hinterland and the micro-distribution involves a huge amount of road transportation as access to remote areas by rail or another mode of transportation is not feasible. The cold chain for healthcare products makes it time-critical to reach the remotest parts of the country making last-mile delivery by smaller vehicles necessary.

d) The adoption of alternative fuels and electric vehicles is very limited and restricted to only metro cities. Therefore, eco-driving and safe driving by trained and healthy drivers with proper routing is essential for minimizing CHGs emissions.

e) For the cement company railway is a major mode of transportation to the extent of about $40 \%$. The healthcare company uses this mode for only about $5 \%$ but the Beverage company is not at all using this mode due to the typical nature of the product which needs a faster turnaround, deeper penetration, and higher consumer touch due to it being a food product. Limitation of reach of the railway in the deepest parts of the Country is a major factor for its low use in general.

f) Air transportation is necessitated for moving healthcare items due to their critical temperature sensitivity which gets jeopardized due to high transit times in a vast country like India. Therefore, the temperature sensitivity of the product and the transit time majorly influence the transportation mode and shipment cost.

g) Besides the impact on the mode of transportation, the different nature of the product also affects the occupancy of goods on vehicles. The beverage company has customized pallets as per SKU which are loaded on the trucks for maximizing capacity utilization while healthcare company has optimized the loading of a typical combination of SKUs as per the size of trucks using the TMS software to maximize the loading efficiency.

\section{Limitations \& Scope for Further Study}

The issue this paper deals in complex and the coverage is limited. Freight transport can cause degradation in soil and water quality, generate waste, besides causing air pollution. While the two dominant modes of freight transportation, i.e. road and rail are studied, to address the aims and objectives elucidated earlier, a far deeper study is called for covering other modes of transportation like inland waterways (though limited as of now), air and pipelines.

Further, the current study has picked organizations in different industry segments namely, Retail/Consumer (Beverage), Healthcare, and Cement. Similar research can be conducted in the same segment/industry to learn how similar or different are the measures being taken by the organizations to limit the emission of harmful GHGs, Carbon and other measures to prevent climate change by two or more companies in the same industry vertical. Such a study would also establish the impact of the competition, if any, on these companies.

This is a qualitative study using a case study method. It would be interesting to conduct quantitative studies in these organizations to understand how various actions in transportation can be measured to arrive at a comparison of various parameters like eco-driving, vehicle routing, etc. 
International Journal of Mathematical, Engineering and Management Sciences

Vol. 5, No. 6, 1091-1107, 2020

https://doi.org/10.33889/IJMEMS.2020.5.6.083

\section{Conflict of Interest}

The author confirms that there is no conflict of interest to declare for this publication.

\section{Acknowledgments}

The author appreciates the effort and guidance provided by Prof (Dr.) Suku Bhaskaran, President, G.D. Goenka University, Gurgaon in conducting this study. This research did not receive any financial grant/funding from any agency in public, commercial, or not-for-profit sectors.to conduct this study. The author also sincerely appreciates the editor and reviewers for their time and valuable comments.

\section{References}

Allen, J., Browne, M., Woodburn, A., \& Leonardi, J. (2012). The role of urban consolidation centres in sustainable freight transport. Transport Reviews, 32(4), 473-490.

Andersson, J., \& Holmberg, B. (2005). Reducing environmental impacts of freight transport sector: the case of the Czech Republic. Thesis Master's Program in Environmental Science. Lund University, Sweden.

Andrieu, C., \& Pierre, G.S. (2012). Comparing the effects of eco-driving training and simple pieces of advice on driving behavior. Procedia - Social and Behavioral Sciences, 54, 211-220.

Arvidsson, N. (2013). The milk run revisited: a load factor paradox with economic and environmental implications for urban freight transport. Transportation Research Part A: Policy and Practice, 51, 5662.

Basu, R. (2016). Full truckload service procurement considering environmental sustainability aspects. Thesis-Faculty of Mech. Engineering. Anna University, Chennai, India. (http://hdl.handle.net/10603/181201).

Basu, R.J., Bai, R., \& Palaniappan, P.K. (2015). A strategic approach to improve sustainability in transportation service procurement. Transportation Research Part E: Logistics and Transportation Review, 74, 152-168.

Brar, G.S., \& Saini, G. (2011, July). Milk run logistics: literature review and directions. In Proceedings of the World Congress on Engineering (Vol. 1, pp. 6-8). London, U.K.

Cerasis: Best practices for effective less than truckload freight shipping. (2014). Retrieved from https://cerasis.com/wp-content/uploads/2014/10/Complete-Guide-To-Effective-LTL-FreightManagement-White-Paper-from-Cerasis.pdf

Coene, S., Arnout, A., \& Spieksma, F.C.R. (2010). On a periodic vehicle routing problem. Journal of the Operational Research Society, 61(12), 1719-1728.

Creswell, J.D. (2009). Research design: qualitative, quantitative, and mixed methods approaches. Sage Publications, Inc. California, USA.

Eisenhardt, K.M. (1989). Building theories from case study research. Academy of Management Review, 14(4), 532-550.

Eurostat: Publications Office of the European Union. (2016). Road freight transport methodology. Luxembourg City, Luxembourg. https://doi.org/10.2785/605303KS-GQ-16-105-EN-N.

Evangelista, P. (2014). Environmental sustainability practices in the transport and logistics service industry: an exploratory case study investigation. Research in Transportation Business \& Management, 12, 6372 .

Evangelista, P., Colicchia, C., \& Creazza, A. (2017). Is environmental sustainability a strategic priority for logistics service providers? Journal of Environmental Management, 198, 353-362. 
International Journal of Mathematical, Engineering and Management Sciences

Vol. 5, No. 6, 1091-1107, 2020

https://doi.org/10.33889/IJMEMS.2020.5.6.083

Gartner. (2017). SCM world future of supply chain. Retrieved from http://www.scmworld.com/wpcontent/uploads/2017/07/Future_of_Supply_Chain_2016_.pdf

Ghiani, G., Laporte, G., \& Musmanno, R. (2004). Introduction to logistics systems planning and control. John Wiley \& Sons, Chichester, England.

Glaser, B.G., \& Strauss, A.L. (1967). The discovery of grounded theory: strategies for qualitative research. Adline de Gruyter, New York.

Jick, T.D. (1979). Mixing qualitative and quantitative methods: triangulation in action. Administrative Science Quarterly, 24(4), 602-611.

Ketokivi, M., \& Choi, T. (2014). Renaissance of case research as a scientific method. Journal of Operations Management, 32(5), 232-240.

Kuznetsov, N.A., Minashina, I.K., Ryabykh, N.G., Zakharova, E.M., \& Pashchenko, F.F. (2016). Design and comparison of freight scheduling algorithms for intelligent control systems. Procedia Computer Science, 98, 56-63.

Lagorio, A., Pinto, R., \& Golini, R. (2016). Research in urban logistics: a systematic literature review. International Journal of Physical Distribution \& Logistics Management, 46(10), 908-931.

Léonardi, J., \& Baumgartner, M. (2004). CO2 efficiency in road freight transportation: status quo, measures, and potential. Transportation Research Part D: Transport and Environment, 9(6), 451-464.

Leonardi, J., Browne, M., Allen, J., Zunder, T., \& Aditjandra, P.T. (2014). Increase urban freight efficiency with delivery and servicing plan. Research in Transportation Business \& Management, 12, 73-79.

Li, C.-L., Vairaktarakis, G., \& Lee, C.-Y. (2005). Machine scheduling with deliveries to multiple customer locations. European Journal of Operational Research, 164(1), 39-51.

Manee-ngam, A., \& Udomsaksigool, A. (2014). Cooperative tactical planning in road transportation with backhauling management. Proceedings of the Asia Pacific Industrial Engineering \& Management Systems Conference (pp. 1256-1263). Bangkok, Thailand.

McKinnon, A.C. (2003). Managing the fundamental drivers of transport demand. Influencing Company Logistics Management, 60-74. Paris, France: OECD Publications Service.

McKinnon, A.C., \& Woodburn, A. (1996). Logistical restructuring and road freight traffic growth. Transportation, 23(2), 141-161.

Miles, M.B., \& Huberman, A.M. (1994). Qualitative data analysis: an expanded sourcebook. Sage Publications. Thousand Oaks, CA.

Ministry of Road Transport and Highways (MoRTH). (2013). Annual report 2013-14. Retrieved December 14, 2019, from https://morth.nic.in/sites/default/files/ilovepdf_merged\%20(2).pdf.

Montreuil, B. (2011). Toward a physical internet: meeting the global logistics sustainability grand challenge. Logistics Research, 3(2-3), 71-87.

Müller, A.-L., \& Pfleger, R. (2014). Business transformation towards sustainability. Business Research, 7(2), 313-350.

OECD Economic Outlook. (2003). Retrieved from https://doi.org/10.1787/eco_outlook-v2003-1-en.

Pagell, M. (2004). Understanding the factors that enable and inhibit the integration of operations, purchasing, and logistics. Journal of Operations Management, 22(5), 459-487.

Pagell, M., \& Wu, Z. (2009). Building a more complete theory of sustainable supply chain management using case studies of 10 exemplars. Journal of Supply Chain Management, 45(2), 37-56. 
International Journal of Mathematical, Engineering and Management Sciences

Vol. 5, No. 6, 1091-1107, 2020

https://doi.org/10.33889/IJMEMS.2020.5.6.083

Piecyk, M.I., \& McKinnon, A.C. (2010). Forecasting the carbon footprint of road freight transport in 2020. International Journal of Production Economics, 128(1), 31-42.

Preuss, L. (2005). Rhetoric and reality of corporate greening: a view from the supply chain management function. Business Strategy and the Environment, 14(2), 123-139.

Rao, P.H. (2019). Green supply chain management: a study based on SMEs in India. Journal of Supply Chain Management Systems, 8(1), 15-24.

Ruan, M., Lin, J., \& Kawamura, K. (2012). Modeling urban commercial vehicle daily tour chaining. Transportation Research Part E: Logistics and Transportation Review, 48(6), 1169-1184.

Schaefer, B., \& Konur, D. (2015). Economic and environmental considerations in a continuous review inventory control system with integrated transportation decisions. Transportation Research Part E: Logistics and Transportation Review, 80, 142-165.

Szeto, W.Y., Jaber, X., \& Wong, S.C. (2012). Road network equilibrium approaches to environmental sustainability. Transport Reviews, 32(4), 491-518.

Tellis, W.M. (1997). Introduction to case study. The Qualitative Report, 3(2), 1-14.

The Behavioral Insights Team. (2019). Behavior change for nature: a behavioral science toolkit for practitioners. $\quad$ Retrieved from https://www.bi.team/search/Behavior+change+for+nature\%3A+a+behavioral+science+toolkit+for+pra ctitioners

U.S. Department of Transportation, Bureau of Transportation Statistics. (2017). Transportation Statistics Annual Report. Washington, DC.

$\begin{array}{lllll}\text { UNEP } 2000 & \text { Annual } & \text { Report. } & \text { (2001). } & \text { Retrieved }\end{array}$ https://digital.library.unt.edu/ark:/67531/metadc25987/m1/4/

Vidal, T., Crainic, T.G., Gendreau, M., Lahrichi, N., \& Rei, W. (2012). A hybrid genetic algorithm for multi depot and periodic vehicle routing problems. Operations Research, 60(3), 611-624.

Wang, Y., Szeto, W.Y., Han, K., \& Friesz, T.L. (2018). Dynamic traffic assignment: a review of the methodological advances for environmentally sustainable road transportation applications. Transportation Research Part B: Methodological, 111, 370-394.

Wu, Z., \& Choi, T.Y. (2005). Supplier-supplier relationships in the buyer-supplier triad: building theories from eight case studies. Journal of Operations Management, 24(1), 27-52.

Yin, R.K. (1984). Case Study Research: design and methods. Sage Publication, Beverly Hills, CA.

Yin, R.K. (1994). Case study research: design and methods. Sage Publication, London.

You, Z., \& Jiao, Y. (2014). Development and application of milk-run distribution systems in the express industry based on saving algorithm. Mathematical Problems in Engineering, 2014, 1-6.

Zainal, Z. (2007). Case study as a research method. Jurnal Kemanusiaan Bil, 5(1), 1-6. Retrieved from https://jurnalkemanusiaan.utm.my/index.php/kemanusiaan/article/view/165/158.

Original content of this work is copyright () International Journal of Mathematical, Engineering and Management Sciences. Uses under the Creative Commons Attribution 4.0 International (CC BY 4.0) license at https://creativecommons.org/licenses/by/4.0/ 